\title{
Correlation of Sillimanite \& Kaliophilite Minerals, TOC, Ro, and MBT from Drill Cutting of Well BS-03 in the Development of Shale Hydrocarbon, Brownshale Formation, Bengkalis Trough, Central Sumatra Basin, Indonesia
}

\author{
Aris Buntoro' ${ }^{1}$, Mohammad Nurcholis ${ }^{2}$, Basuki Rahmad ${ }^{3}$, Allen Haryanto Lukmana ${ }^{1}$ \\ ${ }^{1}$ Petroleum Engineering Departement, UPN “Veteran” Yogyakarta, Yogyakarta, Indonesia \\ ${ }^{2}$ Department of Soil Science, UPN "Veteran” Yogyakarta, Yogyakarta, Indonesia \\ ${ }^{3}$ Department of Geological Engineering, UPN “Veteran” Yogyakarta, Yogyakarta, Indonesia \\ Email: arisbuntoro@upnyk.ac.id
}

How to cite this paper: Buntoro, A., Nurcholis, M., Rahmad, B. and Lukmana, A.H. (2020) Correlation of Sillimanite \& Kaliophilite Minerals, TOC, Ro, and MBT from Drill Cutting of Well BS-03 in the Development of Shale Hydrocarbon, Brownshale Formation, Bengkalis Trough, Central Sumatra Basin, Indonesia. Open Journal of Yangtze Gas and Oil, 5, 216-230.

https://doi.org/10.4236/ojogas.2020.54017

Received: August 21, 2020

Accepted: October 27, 2020

Published: October 30, 2020

Copyright $\odot 2020$ by author(s) and Scientific Research Publishing Inc. This work is licensed under the Creative Commons Attribution International License (CC BY 4.0).

http://creativecommons.org/licenses/by/4.0/ (c) (i) Open Access

\begin{abstract}
Sillimanite is a brittle mineral as a metamorphic mineral product which is generally derived from clay, along with an increase in pressure and high temperature $\left(600^{\circ} \mathrm{C}-900^{\circ} \mathrm{C}\right)$, and kaliophilite is also a brittle mineral as a potassium bearing in the sand-shale series, which contributes to the clay diagenesis process. In the development of shale hydrocarbon in the Brownshale formation in the Bengkalis Trough, Central Sumatra Basin, using the correlation of the XRD (bulk and clay oriented), TOC, Ro, and MBT analysis results from the drill cuttings of well BS-03, so that the fracable zone interval can be determined. From this correlation, it shows that the presence of sillimanite and kaliophilite minerals as minor minerals greatly affects the changes in shale character and hydrocarbon generation, where at depth intervals of $10,780 \mathrm{ft}$ downward (sand series-shale) there is an interesting phenomenon, i.e. low MBT, low TOC, and high Ro, so it is believed that the depth interval of $10,780 \mathrm{ft}$ downward is a fracable zone interval (brittle shale) which is a good candidate for hydraulic fracking planning, while the upper depth interval is a fracture barrier.
\end{abstract}

\section{Keywords}

Sillimanite \& Kaliophilite Minerals, TOC (Total Organic Carbon), Ro (Vitrinite Reflectance), MBT (Methylene Blue Test), Shale Hydrocarbon 


\section{Introduction}

Source rock in the Central Sumatra Basin, consists of four shale formations, namely: the Petani and Telisa Formation [1], Pematang Group [2], and coal Sihapas Group [3]. Based on geochemical analysis, it shows that only the Brownshale formation from Pematang Group is the main rock source in Central Sumatra, which is spread over several sub-basins (troughs), namely: Balam, Rangau, Kiri, Aman, and Bengkalis [4]. The depositional environment of this formation is formed from Lacustrine with lithological rocks consisting of laminated shales, brown in color, rich in organic matter, which indicates a depositional environment with calm water conditions [5].

From the results of previous research, it was stated that in general the Brownshale formation has good prospects for the development of shale hydrocarbon, supported by several parameters, including: TOC (fair - very good), kerogen type II/III, brittleness index greater than 0.48 , and the rock compressive strength is below $70 \mathrm{MPa}[5]$.

The brittleness index is the most widely used parameter to measure the brittleness of rocks [6]. In general brittleness is used as a descriptor in the selection of depth interval for hydraulic fracking planning, so brittleness is one of the most important rock mechanical properties, and is used in determining the prospect of shale hydrocarbon [7] [8] [9] [10] [11].

Mineralogical analysis using XRD (X-ray Diffraction) and MBT (Methyele Blue Test) from drill cuttings data can also be used to determine the type and character of shale [6] [8]-[13].

Sillimanite mineral is a brittle mineral which is a metamorphic mineral product that generally comes from clay, along with the increase in pressure and high

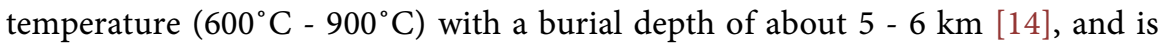
very influential on hydrocarbon generation [15].

Kaliophilite is a mineral brittle, as a potassium-bearing mineral in the sand-shale series [16], contributing to the clay diagenesis process, which can change the character of shale from ductile to brittle, due to the process of changing the reactive smectite mineral to illite or kaolinite as non-reactive mineral [15].

The purpose of this research is to determine the fracable zone interval in the Brownshale formation by using the correlation of the results of XRD (bulk and clay oriented), TOC, Ro, and MBT analysis from drill cuttings of well BS-03, and from this correlation shows that the presence of sillimanite and kaliophilite minerals as minor minerals is very influential on changes in shale character and hydrocarbon generation which correlates with fracable zone interval as good candidates for hydraulic fracking planning.

\section{Study Area, Geological Setting of the Central Sumatra Basin}

\subsection{Bengkalis Trough Study Area}

The well BS-03 is the only well in the study area that penetrates the Brownshale formation of the Pematang Group, as the research target which is located on the 
north side depocenter of the Bengkalis Trough located in Riau Province, Indonesia (Figure 1). Currently the Bengkalis Trough area is managed by two oil company operators, namely the Malacca Strait EMP Group and the CPP Block BOB PT. Bumi Siak Pusako-Pertamina Hulu, which each gave permission and contribution to conduct this research.

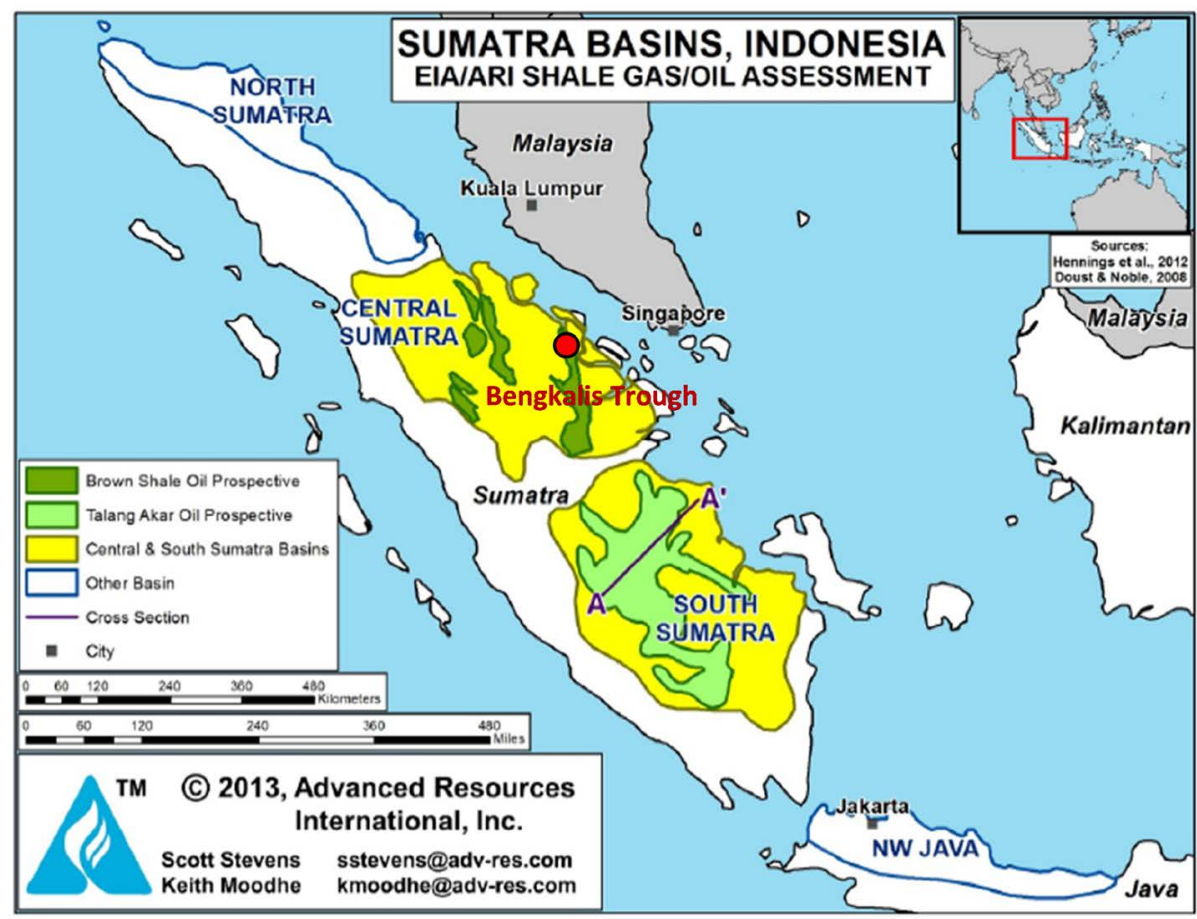

Well Location (BS-03)

Figure 1. Study area of the Bengkalis Trough [17].

\subsection{Geological Setting}

The Central Sumatra Basin was formed during the Early Tertiary (Eocene-Oligocene) as a series of half grabens and horst blocks developed in response to an East-West direction of extensional regime [18]. A divergent transform boundary (non-coupling) between the Sunda Microplate and the Indian Oceanic Plate during Paleogene gave rise to extensional regime and crustal stretching of the western part of the Sunda Land resulting in the formation of Pematang type grabens [19]. Pematang Graben Development can be divided into 4 stages:

- Stage I Pre-Graben (Early Eocene)

During the early Eocene the Indian Ocean Plate was moving $\mathrm{N} 10^{\circ} \mathrm{E}$ [19]. At this time approximate north-south to north-west-southeast lines of weakness with complementary northeast-southwest shears developed. These lines of weakness later became the hinge lines and fault scarps of graben and half-graben structures. During the early to Middle Eocene, the angle of plate convergence increased from $\mathrm{N} 10^{\circ} \mathrm{E}$ to $\mathrm{N} 50^{\circ} \mathrm{E}$ with a resulting minor compressional component [20]. Gentle crustal doming resulting from subduction also began at this time compensating the weak compressional stress, especially in tensional stress sys- 
tem. Incipient block rotation occurred along the earlier developed lines of N-S weakness. Deposition of Lower Red Beds Formation began in developing shallow graben.

- Stage II Graben (Middle Eocene)

Rapid graben development began as a result of relaxation of the Middle Eocene compression by a change in the plate convergence angle to the present $\mathrm{N}$ $20^{\circ}$ E. Deposition of the Brown Shale and Coal Zone Formations occurred during this stage of graben development.

- Stage III Pematang Structuring (Oligocene)

During the late Early Oligocene continued spreading of the graben and increased episodic right-lateral wrench movement occurred resulting in Pematang Structuring.

- Stage IV Lake Fill (Late Oligocene-Early Miocene)

This stage represents the beginning of a tectonic phase resulting in rapid deposition of the Lake Fill Formation. It is characterized by uplift and rapid erosion of highland areas, and culminated with the major unconformity at the end of Pematang deposition. Regional subsidence in the Early Miocene accompanied by a major marine incursion, ended the rift phase of graben development.

The Pematang Group Brownshale Formation is the main source rock of hydrocarbons in the Central Sumatra Basin and is the oldest sedimentary rock aged Eocene to Oligocene which is deposited unconformity in the half-graben [4] [21].

The stratigraphic analysis can be determined by the sequence and distribution of the Brownshale zone. Based on the correlation between wells, it is the most reliable method in stratigraphic analysis, but it cannot be done, because only the well BS-03 penetrates the Brownshale zone. Determination of marker names using tectonic episodes using references from Lambiase (1990), as shown in Figure 2,

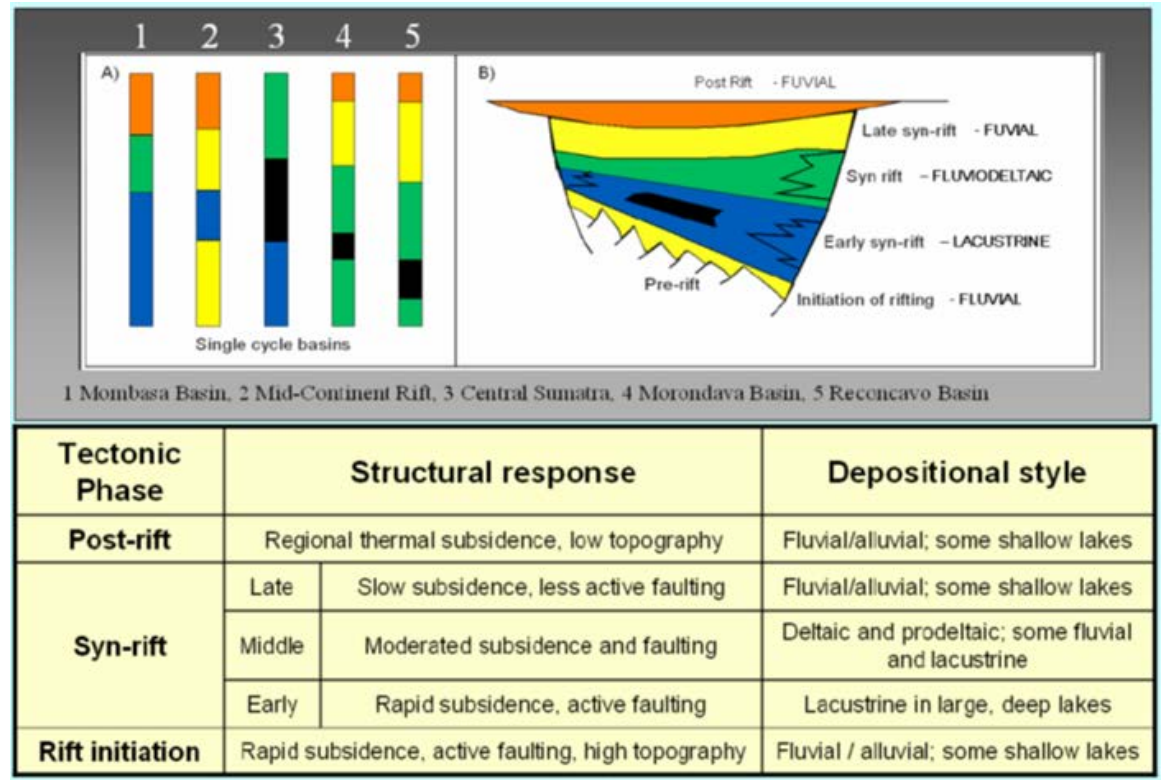

Figure 2. Tectonic episodes, geological structures and depositional environments in several basins [22]. 

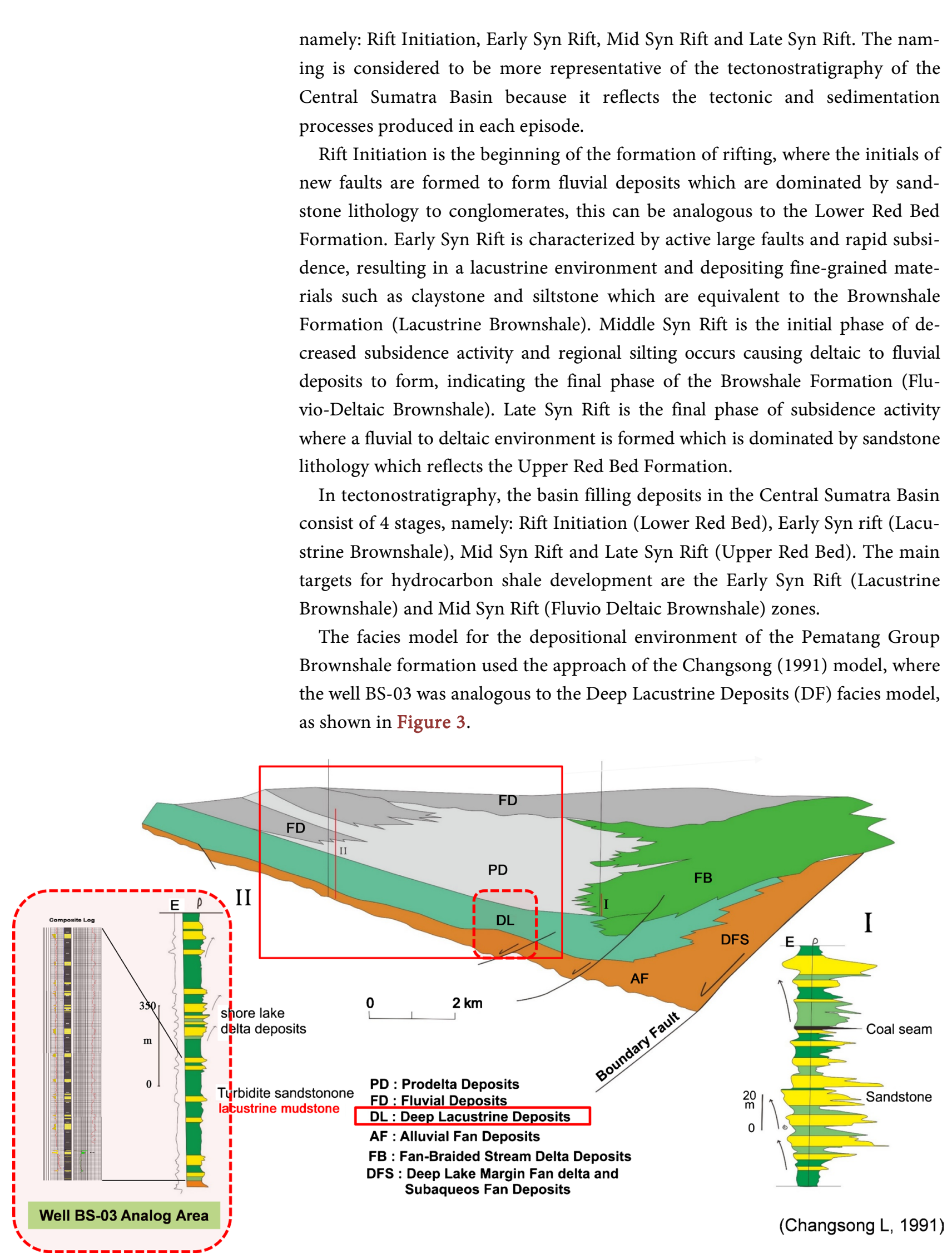

Figure 3. Depositional facies model of lacustrine environment [23]. 


\section{Research Methods}

Figure 4 shows the correlation of XRD, MBT, TOC, and Ro analyzes of drill cuttings to build a fracability model. This research focuses on the Brownshale formation, Pematang Group, Bengkalis Trough, Central Sumatra Basin, Indonesia by correlating the results analysis of drill cuttings data in a flowchart, through several steps to obtain a sweetspot fracable window interval.

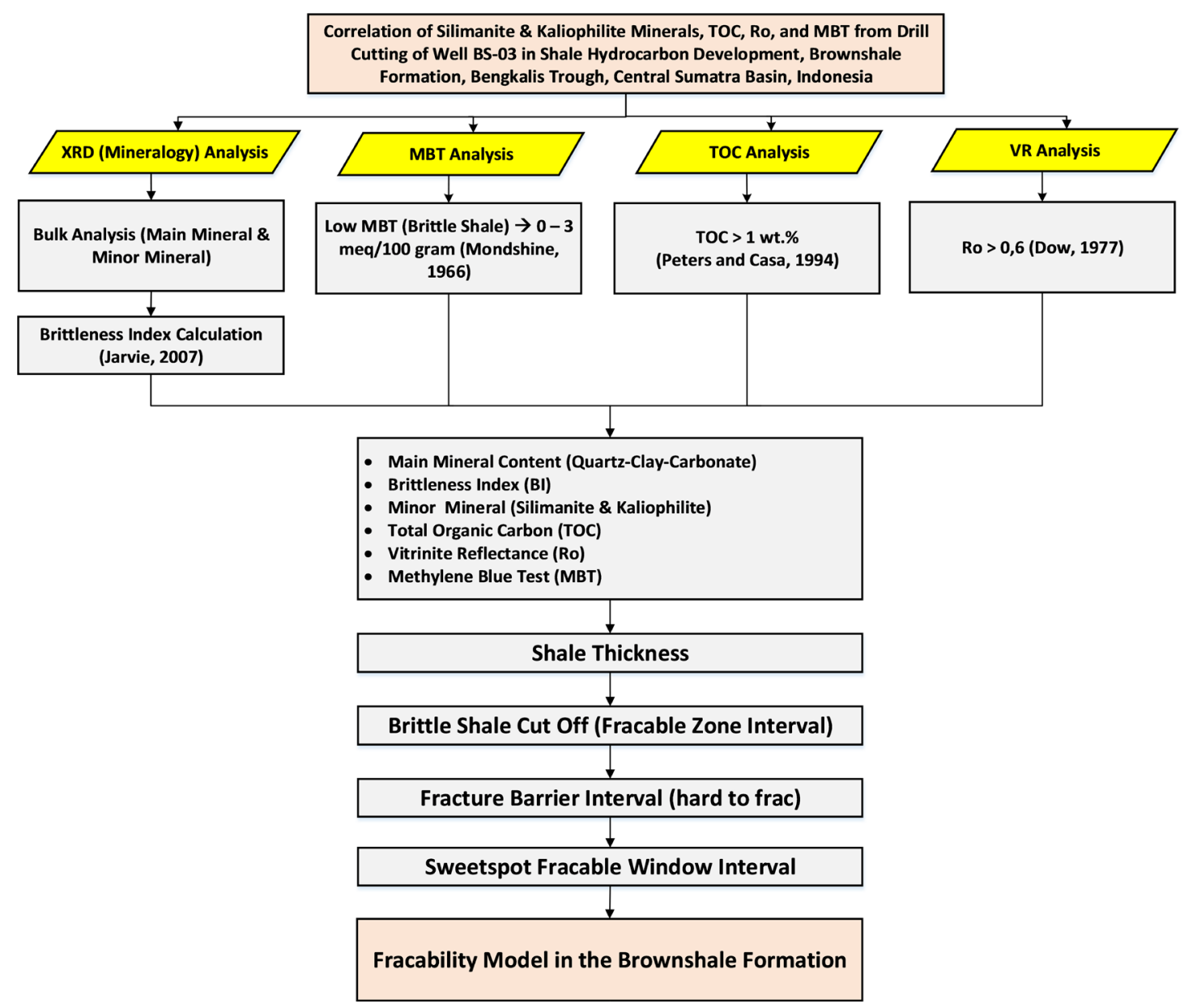

Figure 4. The workflow for the correlation of XRD, MBT, TOC, and Ro analysis from drill cuttings to build a fracability model of the Brownshale formation of well BS-03.

\section{Literature Review}

The types of minerals contained in rock samples can be identified using XRD (X-Ray Diffraction) analysis with the bulk method [24], and the result is that the peaks can be read by the type of mineral based on the determinant peaks [25], and can be categorized into two, namely the major minerals and minor minerals. From the results of the main minerals, namely Quartz, Clay, and Carbonate (Q-C-C), the brittleness index can be determined using the Jarvie Equation (2007), as follows:

$$
B I_{(\mathrm{Jarvie}, 2007)}=\frac{W_{q t z}}{W_{t}}
$$


where:

$B I=$ brittleness index

$W_{q t z}=$ quartz mineral weight

$W_{t}=$ total mineral weight (quartz + clay + carbonate)

The brittleness index is the most widely used parameter to measure the brittleness of rocks [6]. In general, brittleness is used as a descriptor in the selection of formation depth intervals for hydraulic fracking planning, so brittleness is one of the most important rock mechanical properties, and is used in determining the prospect of shale hydrocarbons [9] [10] [11].

Meanwhile, minor minerals include: Feldspar, Apatite, Pyrite, Dolomite, Sillimanite, Kaliophilite, etc. The presence of sillimanite and kaliophilite as minor minerals greatly influences the diagenesis process and the character of shale rocks.

Sillimanite is a brittle mineral as a metamorphic mineral product which generally derived from clay, along with increasing pressure and high temperature $\left(600^{\circ} \mathrm{C}-900^{\circ} \mathrm{C}\right)$ with a burial depth of about $5-6 \mathrm{~km}$ [14]. Kaliophilite is a brittle mineral, as a potassium bearing in the sand-shale series, which contributes to the clay diagenesis process [16].

Mondshine (1966) in his paper presented the shale classification based on MBT and X-ray diffraction (XRD) analysis, namely soft (ductile), firm (less ductile), hard (less brittle), brittle (brittle shale) as shown in Table 1. Babajide (2016) stated that the largest cation exchange rate is owned by allogeneic minerals (source rock fragment), while the smallest is owned by autogenic (chemical processes).

Table 1. Shale classification based on MBT and XRD analysis [6] [12].

\begin{tabular}{rrrrr}
\hline Shale Type & $\begin{array}{r}\text { Related to Hydraulic } \\
\text { Fracking }\end{array}$ & $\begin{array}{r}\text { MBT* } \\
(\mathbf{m e q} / \mathbf{1 0 0})\end{array}$ & $\begin{array}{r}\text { Water Content } \\
(\mathbf{W t} \%)\end{array}$ & Clay Types \\
\hline Soft & Ductile & $20-40$ & $25-70$ & smectite illite \\
Firm & Less Ductile & $10-20$ & $15-25$ & illite mixed layer \\
Hard & Less Brittle & $3-10$ & $5-15$ & illite possibly smectite \\
Brittle & Brittle & $0-3$ & $2-5$ & illite kaolinite chlorite \\
\hline
\end{tabular}

MBT (Methylene Blue Test) is used to determine the ability of clay to bind cations from a solution, namely by using methylene blue to measure the total cation exchange capacity of the clay, where the cation exchange depends on the type and crystallinity of the mineral, the $\mathrm{pH}$ of the solution, the type of cation being exchanged, and the concentration of mineral content contained in clay. MBT values are expressed in pounds per barrel of bentonite-equivalent clay/100lb shale (meq/100grams).

Source rock is a shale rock that contains a lot of carbon elements (high TOC), and has a type of kerogen that has the potential to produce hydrocarbons with a certain degree of maturity. TOC (Total Organic Carbon) values are expressed in percent weight (wt.\%). According to Peters \& Casa (1994), source rock based on TOC values can be classified into 5 types, as shown in Table 2. 
Table 2. Type of source rock [26].

\begin{tabular}{rr}
\hline Type of Source Rock & TOC (wt\%) \\
\hline Poor Source Rock & $0-0.5$ \\
Fair Source Rock & $0.5-1$ \\
Good Source Rock & $1-2$ \\
Very Good Source Rock & $2-4$ \\
Excellent Source Rock & $>4$ \\
\hline
\end{tabular}

Maturity is the process of changing organic substances into hydrocarbons. The maturity process is caused by an increase in temperature below the earth's surface. By knowing the maturity level of a source rock, it can be estimated that the ability of the rock to produce oil or natural gas. The level of maturity of a rock can be determined by Vitrinite Reflectance (Ro). Vitrinite Reflectance (Ro) values are expressed in percent (\%).

In developing shale hydrocarbon commercially based on the results of previous research, several basic criteria are proposed as shown in Table 3.

Table 3. Basic criteria for developing shale hydrocarbon commercially [10] [12] [26] [27].

\begin{tabular}{|c|c|c|}
\hline No & Parameter & Criteria \\
\hline 1 & Total Organic Carbon (TOC), wt.\% & $>1 \mathrm{wt} \%$ \\
\hline 2 & Shale thickness, $\mathrm{ft}$ & $>100 \mathrm{ft}$ \\
\hline 3 & Brittleness Index shale, dimensionless & $>0.48$ \\
\hline \multirow[t]{2}{*}{4} & - Ro, Oil-prone generation, $\%$ & $>0.6 \%$ \\
\hline & - Ro, Gas-prone generation, $\%$ & $>0.8 \%$ \\
\hline \multirow[t]{3}{*}{5} & Fracability Index shale, dimensionless & \\
\hline & - Fracable & $>0.55$ \\
\hline & - Not Fracable (hard to frac) & $\leq 0.55$ \\
\hline 6 & Methylene Blue Test (MBT), Brittle Shale, meq/100g & $\leq 3$ \\
\hline
\end{tabular}

\section{Results and Discussion}

\subsection{XRD \& MBT Analysis Using Drill Cuttings Data of Well BS-03}

The results of semi-quantification calculations from XRD (bulk) analysis of 32 samples of drill cuttings to determine the percentage of minerals at each depth interval are shown in Table 4. From Table 4 it can be seen that ach depth interval the percentage of the main mineral content obtained is Quartz, Clay, and Carbonate, so that the brittleness index can be calculated using the Jarvie equation (2007). From the results of XRD (bulk) analysis, an interesting phenomenon was found, namely the presence of sillimanite and kaliophilite minerals in the Brownshale formation which was significantly started at a depth interval of 10,780 ft downward, both of which belong to the brittle mineral category [25].

From Table 4 based on minor minerals group, there is an interesting 
Table 4. Results of semi-quantification calculations from XRD (bulk) and MBT analysis at the depth interval of 10420 - 11642 feet well BS-03.

\begin{tabular}{|c|c|c|c|c|c|c|c|c|c|c|c|c|}
\hline \multirow[b]{2}{*}{ No } & \multicolumn{6}{|c|}{ Main Mineral } & \multicolumn{4}{|c|}{ Minor Mineral } & \multirow[b]{2}{*}{ Total } & \multirow[b]{2}{*}{$\begin{array}{r}\text { MBT } \\
\text { (meq/100gr) }\end{array}$} \\
\hline & Depth (ft) & $\begin{array}{r}\text { Quartz } \\
(\%)\end{array}$ & $\begin{array}{r}\text { Calcite } \\
(\%)\end{array}$ & $\begin{array}{r}\text { Clay } \\
(\%)\end{array}$ & $\begin{array}{r}\text { Feldspar } \\
(\%)\end{array}$ & $\begin{array}{r}\text { Apatite } \\
(\%)\end{array}$ & $\begin{array}{r}\text { Pyrite } \\
(\%)\end{array}$ & $\begin{array}{r}\text { Dolomite } \\
(\%)\end{array}$ & $\begin{array}{r}\text { Sillimanite } \\
(\%)\end{array}$ & $\begin{array}{r}\text { Kaliophilite } \\
(\%)\end{array}$ & & \\
\hline 1 & $10,420-10,430$ & 70.94 & 0.00 & 4.84 & 13.82 & 0.00 & 3.26 & 2.73 & 4.42 & 0.00 & 100.00 & 8 \\
\hline 2 & $10,460-10,470$ & 63.95 & 0.00 & 12.63 & 9.70 & 0.00 & 3.70 & 5.33 & 4.69 & 0.00 & 100.00 & 5. \\
\hline 3 & $10,500-10,510$ & 48.45 & 4.74 & 15.45 & 10.90 & 2.27 & 3.83 & 4.23 & 5.39 & 4.74 & 100.00 & 6.5 \\
\hline 4 & $10,540-10,550$ & 61.35 & 0.00 & 8.48 & 11.23 & 4.25 & 5.01 & 4.45 & 5.22 & 0.00 & 100.00 & 4 \\
\hline 5 & $10,580-10,590$ & 57.82 & 0.00 & 12.07 & 12.34 & 0.00 & 5.00 & 6.64 & 6.14 & 0.00 & 100.00 & 4.5 \\
\hline 6 & $10,620-10,630$ & 60.90 & 0.00 & 11.07 & 7.09 & 4.38 & 4.45 & 5.42 & 6.69 & 0.00 & 100.00 & 8 \\
\hline 7 & $10,660-10,670$ & 72.88 & 0.00 & 7.67 & 9.93 & 0.00 & 3.47 & 3.03 & 3.00 & 0.00 & 100.00 & 6.5 \\
\hline 8 & $10,700-10,710$ & 58.21 & 0.00 & 14.63 & 9.14 & 2.44 & 4.11 & 7.02 & 4.45 & 0.00 & 100.00 & 8 \\
\hline 9 & $10,740-10,750$ & 72.47 & 0.00 & 14.20 & 5.58 & 0.00 & 3.44 & 4.31 & 0.00 & 0.00 & 100.00 & 7 \\
\hline 10 & $10,780-10,790$ & 62.40 & 0.00 & 11.98 & 7.88 & 3.23 & 4.11 & 4.61 & 5.80 & & 100.00 ' & \\
\hline 11 & $10,820-10,830$ & 43.49 & 2.78 & 13.02 & 4.86 & 8.11 & 4.44 & 5.80 & 9.62 & $7.89 !$ & 100.00 & 5.5 \\
\hline 12 & $10,860-10,870$ & 55.76 & 0.00 & 5.17 & 7.85 & 3.68 & 3.72 & 5.45 & 10.73 & $7.65 i$ & 100.00 & 5 \\
\hline 13 & $10,900-10,910$ & 45.63 & 0.00 & 13.66 & 7.28 & 5.26 & 4.14 & 4.70 & 13.20 & $6.13 \mid$ & 100.00 & 5 \\
\hline 14 & $10,940-10,950$ & 41.58 & 2.08 & 9.99 & 6.11 & 5.25 & 4.38 & 5.12 & 15.30 & 10.18 & 100.00 & 3 \\
\hline 15 & $10,980-10,990$ & 32.24 & 0.00 & 11.97 & 10.90 & 6.24 & 4.47 & 7.30 & 15.34 & $11.54_{1}^{I}$ & 100.00 & 6 \\
\hline 16 & $11,020-11,030$ & 29.97 & 5.55 & 8.56 & 7.22 & 5.82 & 2.46 & $5.09 !$ & 23.24 & 12.08 & 100.00 & $5.5^{\prime}$ \\
\hline 17 & $11,060-11,070$ & 60.40 & 3.89 & 6.05 & 6.36 & 3.18 & 2.97 & 3.55 & 7.44 & 6.16 & 100.00 & 3 \\
\hline 18 & $11,100-11,110$ & 41.59 & 2.33 & 8.59 & 8.47 & 5.63 & 3.23 & 5.85 & 14.26 & 10.05 & 100.00 & 2.5 \\
\hline 19 & $11,140-11,150$ & 38.35 & 2.73 & 6.67 & 8.62 & 5.06 & 5.84 & 5.09 & 15.05 & $12.58_{\mid}^{1}$ & 100.00 & 2 \\
\hline 20 & $11,180-11,190$ & 42.39 & 0.00 & 10.85 & 6.19 & 5.99 & 4.51 & 6.94 & 14.94 & $8.20_{1}^{1}$ & 100.00 & 2 \\
\hline 21 & $11,220-11,230$ & 62.18 & 0.00 & 10.90 & 4.87 & 2.80 & 3.57 & 3.34 & 7.03 & 5.30 & 100.00 & $2.5^{1}$ \\
\hline 22 & $11,260-11,270$ & 37.50 & 0.00 & 9.65 & 11.47 & 7.54 & 3.64 & 5.73 & 14.47 & $9.99 !$ & 100.00 & $2.5^{1}$ \\
\hline 23 & $11,300-11,310$ & 44.35 & 3.65 & 9.06 & 9.39 & 4.54 & 4.14 & 6.02 & 11.31 & $7.55_{\mid}^{1}$ & 100.00 & 1.5 \\
\hline 24 & $11,340-11,350$ & 46.37 & 0.00 & 9.38 & 6.20 & 5.27 & 3.77 & 4.90 & 12.18 & $11.92_{1}^{i}$ & 100.00 & 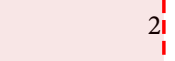 \\
\hline 25 & $11,380-11,390$ & 63.29 & 0.00 & 5.09 & 3.34 & 3.30 & 4.01 & 3.20 & 10.77 & $7.00_{1}^{\prime}$ & 100.00 & $4.5^{\prime}$ \\
\hline 26 & $11,420-11,430$ & 33.81 & 0.00 & 12.60 & 9.33 & 6.32 & 4.37 & $7.23 !$ & 14.79 & $11.56 !$ & 100.00 & $5.5^{1}$ \\
\hline 27 & $11,460-11,470$ & 56.57 & 0.00 & 7.19 & 0.00 & 6.16 & 3.89 & 4.86 & 11.00 & $10.32 !$ & 100.00 & $5.5_{1}^{1}$ \\
\hline 28 & $11,500-11,510$ & 57.90 & 0.00 & 9.04 & 4.11 & 3.31 & 3.37 & 4.07 & 10.27 & 7.93 & 100.00 & 3.5 \\
\hline 29 & $11,540-11,550$ & 38.68 & 13.26 & 12.70 & 5.01 & 5.57 & 3.75 & 5.32 & 8.77 & 6.94 & 100.00 & 4 \\
\hline 30 & $11,580-11,590$ & 23.26 & 7.53 & 13.45 & 7.35 & 7.63 & 3.32 & 7.25 & 16.86 & 13.36 & $100.00 i$ & 4 \\
\hline 31 & $11,620-11,630$ & 41.80 & 0.00 & 17.20 & 0.00 & 9.25 & 3.94 & 5.10 & 13.27 & $9.42 !$ & 100.00 & 4 \\
\hline 32 & 11,642 & 32.47 & 3.91 & 14.46 & 6.81 & 8.00 & 3.37 & 5.98 & 12.58 & $12.422^{\prime}$ & 100.00 & $6.5^{1}$ \\
\hline
\end{tabular}


phenomenon, namely the presence of sillimanite and kaliophilite minerals which significantly appear starting at a depth interval of $10,780 \mathrm{ft}$ downward, where both minerals have a brittle tenacity [25], so they can be categorized as brittle minerals.

The result of the MBT analysis also shows an interesting phenomenon, namely at a depth interval of about $10,780 \mathrm{ft}$ the value drops below $3 \mathrm{meq} / 100 \mathrm{~g}$, indicating the category of brittle shale [12].

Referring to the presence of the sillimanite and kaliophilite minerals (brittle minerals), as well as the low MBT value (brittle shale), then at the interval of $10,780 \mathrm{ft}$ downward it is believed to be is a fracable zone interval (brittle shale) which is a good candidate for hydraulic fracking planning, while the upper depth interval is a fracture barrier.

\subsection{Correlation of Lithofacies with XRD (Bulk), MBT, TOC, Ro Analysis of Drill Cuttings and Total Gas from Composite Log Data of Well BS-03}

The correlation of lithofacies with the results of XRD (bulk), MBT, TOC, Ro analysis from drill cuttings, and total gas from composite log data of well BS-03 is shown in Figure 5, which shows a strong correlation with the depth interval in the sand-shale series. This can confirm the fracability model, i.e.:

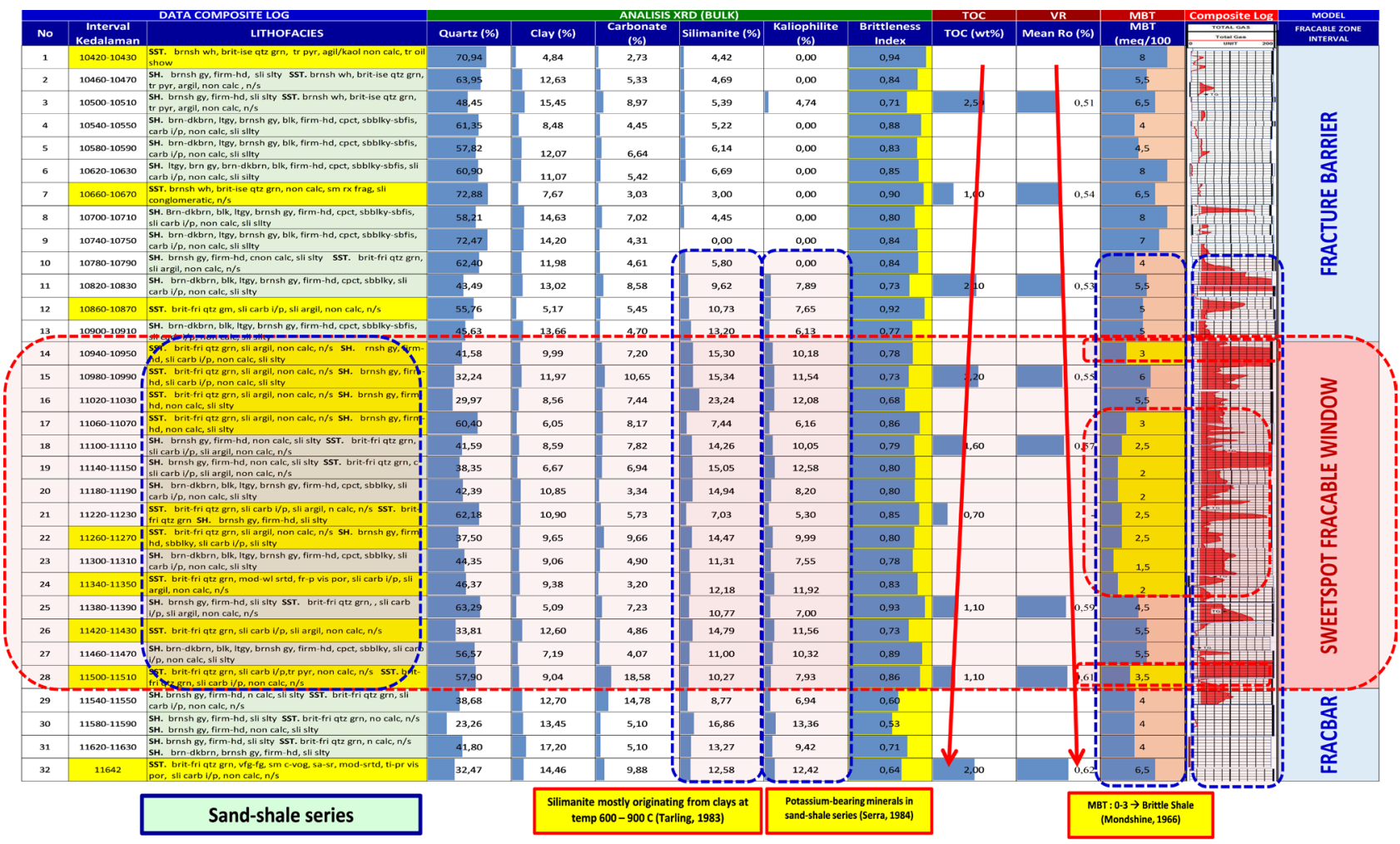

Figure 5. Correlation of lithofacies with the results of XRD (bulk), MBT, TOC, Ro analysis from drill cuttings, and total gas from the composite log data of well BS-03.

a) At the depth interval of the sand-shale series, sillimanite is present, which is a brittle mineral as a result of alteration from clay at high temperatures $\left(600^{\circ} \mathrm{C}\right.$ - 
$900^{\circ} \mathrm{C}$ ), which supports the hydrocarbon generation process, and it is proven that at this depth interval Ro reaches a value of greater than $0.6 \%$.

b) The presence of kaliophilite, which is a brittle mineral, as a potassium-bearing mineral in the sand-shale series, contributes to the clay diagenesis process.

c) The value of MBT at the depth interval of the sand-shale series is generally low MBT, and has a strong correlation with low TOC and high Ro. This is in accordance with item a), where the deeper the maturity (Ro) is higher, so that the TOC value decreases.

d) Sand-shale series interval is the most prospective Brownshale formation interval to produced hydrocarbon, based on items a), b), c), and the total gas from the composite log data of well BS-03.

\subsection{Correlation of Lithofacies with XRD (Clay Oriented), MBT, TOC, Ro Analysis of Drill Cuttings and Total Gas from Composite Log Data of Well BS-03}

From the correlation of lithofacies with the results of XRD (Clay Oriented) analysis, MBT, TOC, Ro from drill cuttings, and total gas from the composite log data of well BS-03 is shown in Figure 6, which shows the dominance of kaolinite and illite clay minerals compared to the other clay minerals, with the following explanation:

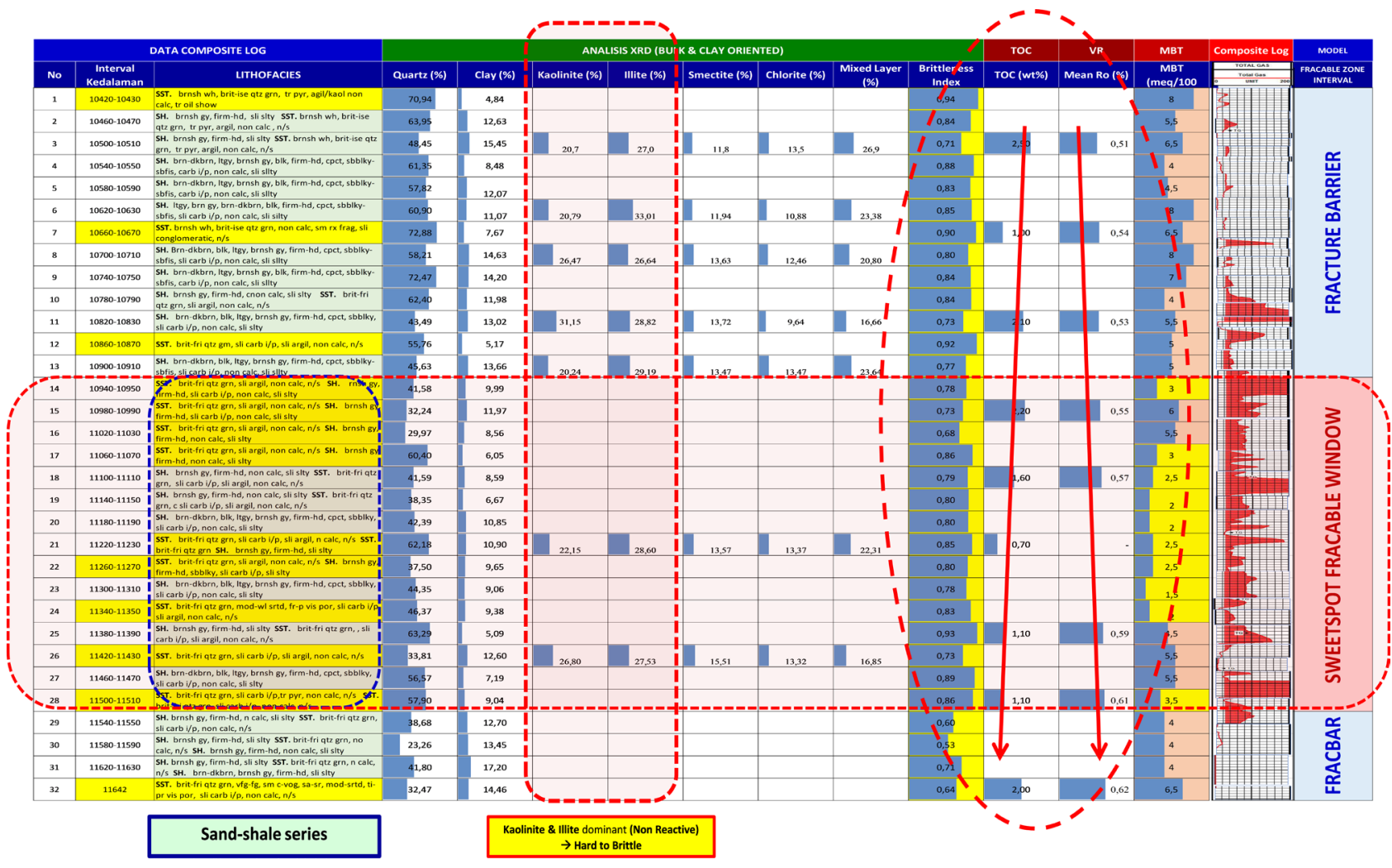

Figure 6. Correlation of lithofacies with the results of XRD (Clay Oriented) analysis, MBT, TOC, Ro from drill cuttings, and total gas from the composite log data.

The dominance of kaolinite and illite minerals as non-reactive minerals (hard 
- brittle), where both minerals are products of clay diagenesis, the results can be seen in the ternary diagram (Figure 7), namely smectite due to the influence of high temperature and the presence of potassium $\left(\mathrm{K}^{+}\right)$minerals, which is supported by the sand-shale series environment changes to illite (kaolinite), silica, and $\mathrm{H}_{2} \mathrm{O}$ with the following chemical reactions:
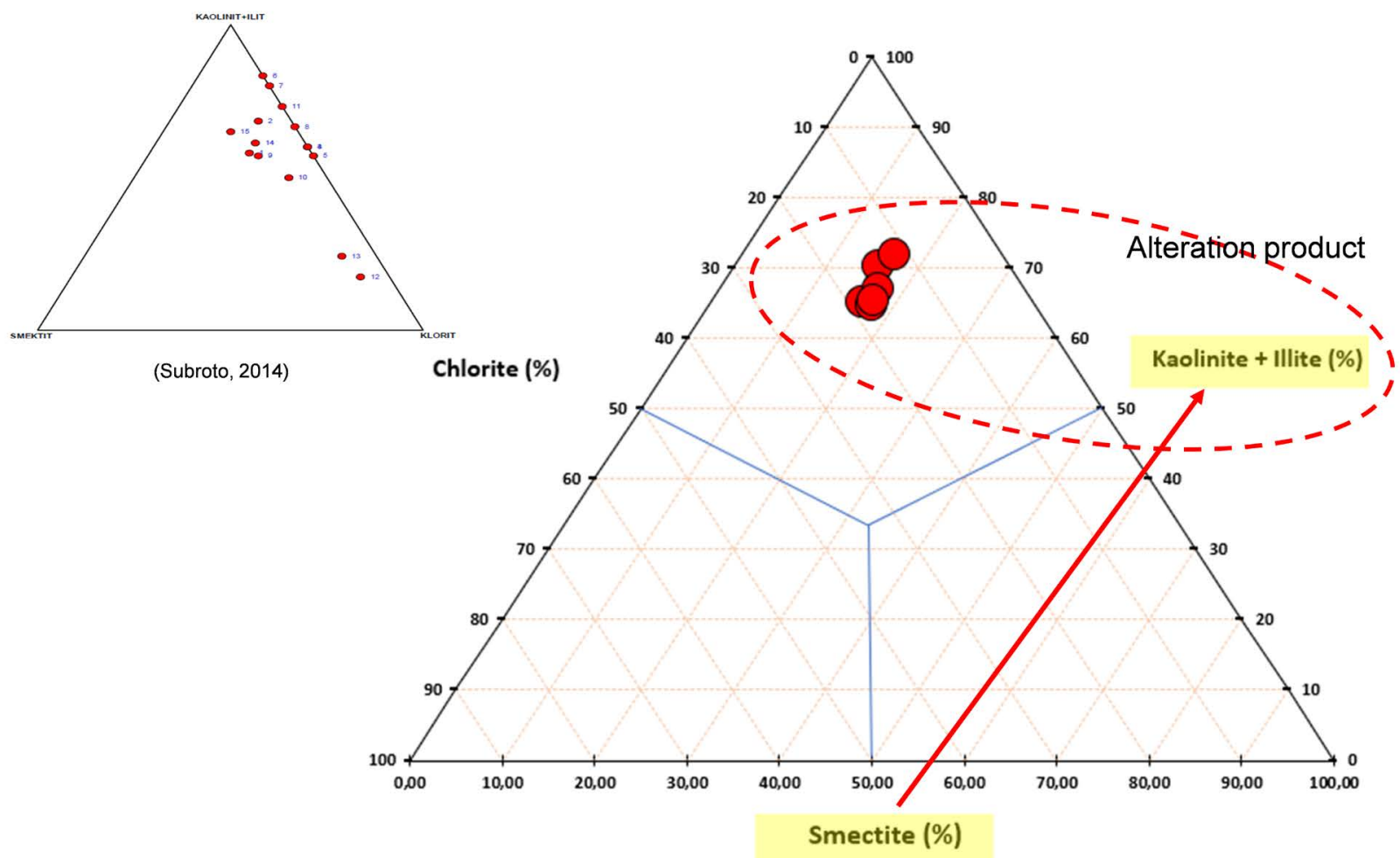

(Modified from Subroto, 2014)

Figure 7. Ternary diagram of the results of XRD (Clay Oriented) analysis from drill cuttings of well BS-03 [29].

$$
\text { Smectite }+\mathrm{K}^{+} \rightarrow \text { Illite }+ \text { Silica }+\mathrm{H}_{2} \mathrm{O}
$$

This reaction will produce water $\left(\mathrm{H}_{2} \mathrm{O}\right)$, causing an increase in pore pressure [15] [28].

\section{Conclusions}

1) Brittleness index based on XRD (bulk) analysis shows that the entire depth interval of the Brownshale formation (10,420 - 11,642 ft) is above 0.48 (brittle category), but based on the MBT analysis, not all depth intervals are brittle shale which correlates with the fracable zone interval.

2) At the depth interval of the sand-shale series, there is sillimanite mineral, which is a brittle mineral as a result of alteration from clay at high temperatures $\left(600^{\circ} \mathrm{C}-900^{\circ} \mathrm{C}\right)$, which supports the hydrocarbon generation process, and it is proven that at this depth interval Ro reaches a value of greater than $0.6 \%$.

3) The presence of kaliophilite, which is a brittle mineral, as a potassium-bearing mineral in the sand-shale series, contributes to the clay diagenesis process, which 
causes changes in the character of shale which was originally ductile because it is dominated by smectite mineral, along with hydrocarbon generation to become brittle shale which is dominated by kaolinite and illite minerals, and confirmed from the results of the MBT analysis which showed that the sand-shale series depth interval was generally low MBT (brittle shale category).

4) Sand-shale series interval is the most prospective Brownshale formation interval to produce hydrocarbon based on items 2,3 , and the total gas depth interval from the composite log data of well BS-03.

5) Kaolinite and illite minerals dominate at depth intervals in the sand-shale series environment which is rich in potassium $\left(\mathrm{K}^{+}\right)$mineral, as the product of clay diagenesis.

\section{Acknowledgements}

The authors thank Malacca Strait EMP Group and CPP Block BOB PT. Bumi Siak Pusako-Pertamina Hulu for contributing data and permission for publication.

\section{Conflicts of Interest}

The authors declare no conflicts of interest regarding the publication of this paper.

\section{References}

[1] Wongsosantiko, A. (1976) Lower Miocene Duri Formation Sands, Central Sumatra Basin. Proceedings 5th Annual Convention Indonesian Petroleum Association, Jakarta, Indonesia, 7-8 June 1976, 63-76. https://gsmpubl.files.wordpress.com/2014/09/bgsm1995a04.pdf

[2] Williams, H.H., Kelley, P.A., Janks, J.S. and Christensen, R.M. (1985) The Paleogene Rift Basin Source Rocks of Central Sumatra. Proceedings 14th Annual Convention Indonesian Petroleum Association, Vol. 2, 57-90. https://pubs.usgs.gov/fs/2015/3072/fs20153072.pdf https://doi.org/10.29118/IPA.96.57.90

[3] MacGregor, D.S. and McKenzie, A.G. (1986) Quantification of Oil Generation and Migration in the Malacca Strait Region Central Sumatra. Proceedings 15th Indonesian Petroleum Association Annual Convention, Vol. 1, 305-320. https://pdfs.semanticscholar.org/441a/6774d795592c44bc1877aad3a854b7ec06b9.pdf

[4] Katz, et al. (1994) Stratigraphic and Lateral Variations of Source Rock Attributes of the Pematang Formation, Central Sumatra. AAPG International Conference \& EXhibition ‘94, Kuala Lumpur, 21-24 August 1994, Kuala Lumpur, Malaysia, 13-31. https://gsm.org.my/products/702001-100964-PDF.pdf

[5] Haris, et al. (2017) Shale Hydrocarbon Potential of Brown Shale, Central Sumatera Basin Based on Seismic and Well Data Analysis. IOP Conference Series: Earth and Environmental Science, 62, Article ID: 012018. https://iopscience.iop.org/article/10.1088/1755-1315/62/1/012018/meta https://doi.org/10.1088/1755-1315/62/1/012018

[6] Perez, R. and Marfurt, K. (2013) Calibration of Brittleness to Elastic Rock Properties via Mineralogy Logs in Unconventional Reservoirs. University of Oklahoma, Norman.

http://www.searchanddiscovery.com/documents/2013/41237perez/ndx_perez.pdf 
[7] Bai (2016) Why Are Brittleness and Fracability Not Equivalent in Designing Hydraulic Fracturing in Tight Shale Gas Reservoirs. Petroleum, 2, 1-19.

https://www.researchgate.net/publication/301693810

https://doi.org/10.1016/j.petlm.2016.01.001

[8] Buntoro, et al. (2020) Shale Hydrocarbon Development Based on Drill Cuttings \& TOC Analysis: Case Study of Brownshale Drill Cuttings of Well BS-03, Pematang Formation, Bengkalis Trough, Central Sumatra Basin. Open Journal Yangtze Oil and Gas, 5, 87-102. https://doi.org/10.4236/ojogas.2020.53008

[9] Jarvie, et al. (2007) Unconventional Shale Gas System: The Mississippian Barnet Shale of North-Central Texas as One mMdel for Thermogenic Shale Gas Assessment. AAPG Bulletin, 91, 475-499. https://doi.org/10.1306/12190606068

[10] Jin, et al. (2014) Fracability Evaluation in Shale Reservoirs-An Integrated Petrophysics and Geomechanics Approach. SPE Hydraulic Fracturing Technology Conference, The Woodlands, 4-6 February 2014, SPE-168589-MS. https://www.onepetro.org/conference-paper/SPE-168589-MS https://doi.org/10.2118/168589-MS

[11] Jinbu, et al. (2015) Fracability Evaluation of the Unconventional Mud-Shale Reservoir. University of Petroleum (East China), Qingdao.

[12] Mondshine, et al. (1966) Shale Dehydration Studies Point Way to Successful Gumbo Shale Drilling. Oil \& Gas Journal, 194-205.

[13] Babajide (2016) Effect of Temperature and Pressure on Shale Cuttings Dispersion. SPE-184310-MS. https://www.researchgate.net/publication/304999224

[14] Tarling (1983) Palaeomagnetism, Principles and Aplications in Geology, Geophysics and Archeology. Chapman and Hall Ltd., London.

https://books.google.co.id/books?id=1499CAAAQBAJ\&pg=PA66\&lpg=PA66\&dq=S $\underline{\text { illimanite }+ \text { diagenesis\# } \mathrm{v}=\text { onepage } \& \mathrm{q}=\text { Sillimanite } \% 20 \text { diagenesis } \& \mathrm{f}=\text { false }}$

[15] Swarbrick, et al. (2002) Comparison of Overpressure Magnitude Resulting from the Main Generating Mechanisms. American Association of Petroleum Geologists (AAPG) Memoir, January 2002.

https://www.researchgate.net/publication/264739600

[16] Sierra (1984) Fundamentals of Well Log Interpretation, the Acquisition of Logging Data. Elsevier Science Publishing Company Inc., Amsterdam.

https://books.google.co.id/books?id=K6K6ha14yVQC\&pg=PA102\&dq=kaliophilite + diagenesi $\# \mathrm{v}=$ onepage $\& \mathrm{q}=$ kaliophilite\%20diagenesi\&f=false

[17] NN (2015) Technically Recoverable Shale Oil and Gas Resources in Indonesia. U.S. Energy Information Administration (EIA). https://www.eia.gov/analysis/studies/worldshalegas

[18] Eubank, R.T. and Makki, A.C. (1981) Structural Geology of the Central Sumatra Back-Arc Basin. Proc., Indonesian Petroleum Association, 10 th Ann. Conv., Jakarta, 26-27 May 1981, 153-174. https://doi.org/10.29118/IPA.203.153.196

https://www.worldcat.org/title/structural-geology-of-the-central-sumatra-back-arcbasin/oclc/36619766

[19] Davis, R.C., Ardjakusumah, W.O. and Soemantri, I.S. (1998) Kinetic Modeling of the Pematang-Sihapas Petroleum System, Malacca Strait PSC, Central Sumatra. Proceedings 26th Indonesian Petroleum Association Annual Convention, Jakarta, 1, 35-50. http://www.vangorselslist.com/pdf/BIG_II_Sundaland_7.pdf

[20] Karig, D.E., Suparka, S., Moore, G.F. and Hehanusa, P.E. (1979) Structure and Cenozoic Evolution of the Sunda Arc in the Central Sumatra Region. In: Watkins, J.S., Montadert, L. and Dickenson, P.W., Eds., Geological and Geophysical Investiga- 
tions of Continental Margins, American Association of Petroleum Geologists, Tulsa, Memoirs 29, 223-237.

https://jgsm.geologi.esdm.go.id/index.php/JGSM/article/view/131

[21] Heidrick, T.L. and Aulia, K. (1993) A Structural and Tectonic Model of the Coastal Plains Block, Central Sumatra Basin, Indonesia. 22nd Annual Convention Proceedings, Volume 1, 285-317.

http://archives.datapages.com/data/ipa/data/022/022001/285_ipa022a0285.htm

[22] Lambiase (1990) A Model for Tectonic Control of Lacustrine Stratigraphic Sequences in Continental Rift Basins. In: Katz, B.J., Ed., Lacustrine Basin Exploration: Case Studies and Modern Analogs, American Association of Petroleum Geologists Memoir 50, Tulsa, 265-276. https://store.aapg.org/detail.aspx?id=ADD-564

[23] Changsong, et al. (1991) Structural and Depositional Patterns of the Tertiary Baise Basin, Guang Xi Autonomous Region (Southeastern China): A Predictive Model for Fossil Fuel Exploration. The International Association of Sedimentologists.

[24] Bragg, W.H. (1913) The Reflection of X-Rays by Crystals. Nature, 91, 477. https://doi.org/10.1038/091477b0

[25] Bladh (2001) Handbook of Mineralogy. http://www.handbookofmineralogy.org

[26] Peters and Casa (1994) Applied Source Rock Geochemistry, the Petroleum System: From Source to Trap. American Association of Petroleum Geologists, Tulsa, 93-120. https://www.scirp.org/(S(351jmbntvnsjtlaadkposzje))/reference/ReferencesPapers.a spx?ReferenceID $=1556455$

[27] McKeon (2011) Horizontal Fracturing in Shale Plays. Halliburton. https://www.slideserve.com/eshana/horizontal-fracturing-in-shale-plays-matt-mcke on

[28] Powers (1967) Compaction and Fluid Migration, Practical Petroleum Geology. Development in Petroleum Science, Volume 9. https://www.sciencedirect.com/science/article/pii/S0376736108701146

[29] Subroto, et al. (2013) Integratrated 3G Study of Lower Baong Shale Formation in North Sumatra Basin. https://www.researchgate.net/publication/266672039 